\title{
FDI and Make in India
}

\author{
V. Sureshbabu, R. Vinitha
}

\begin{abstract}
Foreign Direct Investment (FDI) is viewed as a source of economic development, modernization, employment, and income growth for emerging economies like India. It acts as a significant catalyst and as the lifeblood of economic development by way of up-gradation of technology, managerial skills, capabilities, etc., The main advantage of FDI is that it supplements the available domestic capital without adding to the national debt. A steady and continuous inflow of foreign investments helps in boosting our Balance of Payments situations and strengthening the value of Indian currency against global currencies. India has liberalized its FDI regimes and pursued several other policies to make India an attractive destination for FDI. Government of India has taken strenuous efforts and initiatives in recent years like dispensing the need of getting approvals at various stages from the Government /other regulatory bodies and relaxing FDI norms across various sectors such as Defence, Public Sector Undertaking Oil refineries, Telecom sector, Stock exchanges, etc., Major initiative in this regard is the "Make in India" launched by the Prime Minister Shri. Narendra Modi in September 2014. Make in India is a powerful, galvanizing call and an invitation to potential investors around the world to transform India into a global design and manufacturing hub. Tackling the problems of unemployment by creation of new jobs, advancement of employability skills and fostering innovation are the major objectives of this initiative. Series of reforms launched by the Government of India to liberalize its foreign investment norms has enabled our country to be one of the world's fastest-growing economies and a top market for foreign direct investments globally. This paper attempts to analyze the FDI in various sectors and the impact of Make in India scheme on FDI.
\end{abstract}

Keywords : FDI, Economic Development, Make in India, Manufacturing hub.

\section{INTRODUCTION}

The process of liberalization and economic reforms in 1991 has boosted the flow of foreign investment by making the FDI route to India more accessible. FDI can enter into India through two courses. One being Automatic route where no approval of the Government is required by the private foreign investor and second Government route where investment is not possible without the prior permission of the Government of India. Many FDI Policy reforms have been undertaken by the Government of India since 2014-15 making it an investor-friendly policy. 100\% FDI under automatic route is permitted for most of the sectors. FDI policy is reviewed by the government continuously to

Revised Manuscript Received on September 25, 2019

* Correspondence Author

Dr. V. SURESHBABU, Assistant Professor, PG \& Research Department of Commerce, Mannar Thirumalai Naicker College, Pasumalai, Madurai - 625 004, Tamil Nadu, India

R. VINITHA, Assistant Professor, PG \& Research Department of Commerce, Rajapalayam Rajus' College, Rajapalayam - 626117, Tamil Nadu, India liberalize the system and to provide ease of doing business in the country.

\section{FDI AND ITS ROUTES}

The investors making an investment under automatic route need not obtain the prior approval of the Government of India or the Reserve Bank of India (RBI). They are only required to notify the concerned regional office of the RBI within 30 days of receipt of inward remittances and file the wanted documents with that office within 30 days of issuance of shares to foreign investors. Whereas under the Government approval route, the proposals are considered in a time-bound and transparent manner by the Foreign Investment Promotion Board (FIPB). Approvals of composite projects involving foreign investment/ foreign technical collaboration are also granted on the recommendations of the FIPB.

\section{SECTORAL CAPS FOR FDI IN INDIA}

The following table summarizes the Sectoral Cap/Limit under the Current FDI policy of India. 


\begin{tabular}{|c|c|c|}
\hline SECTOR & $\begin{array}{c}\text { FDI } \\
\text { CAP/LIMIT }\end{array}$ & $\begin{array}{c}\text { ENTRY } \\
\text { ROUTE }\end{array}$ \\
\hline $\begin{array}{c}\text { A. Agriculture } \\
\text { 1. Floriculture, Horticulture, Development of Seeds, } \\
\text { Animal Husbandry, Aquaculture, Pisciculture, } \\
\text { Cultivation of vegetables \& mushrooms and services } \\
\text { related to agro and allied sectors } \\
\text { 2. Tea sector, including plantation } \\
\text { (Any other agricultural sector /activity is not allowed in FDI) }\end{array}$ & $100 \%$ & Automatic \\
\hline $\begin{array}{l}\text { B. Industry } \\
\text { 1. Mining covering exploration and mining of precious } \\
\text { stones, diamonds, gold, silver, and minerals. } \\
\text { 2. Coal and lignite mining for restricted consumption } \\
\text { by power projects, and steel } \\
\text { 3. \& iron, Mineral separation of titanium bearing } \\
\text { minerals and cement production Mining. }\end{array}$ & $\begin{array}{l}100 \% \\
100 \% \\
100 \%\end{array}$ & $\begin{array}{c}\text { Automatic } \\
\text { Automatic } \\
\text { FIPB }\end{array}$ \\
\hline $\begin{array}{l}\text { C. Manufacturing } \\
\text { 1. Alcohol- Distillation \& Brewing } \\
\text { 2. Coffee \& Rubber processing \& Warehousing } \\
\text { 3. Defense Production } \\
\text { 4. Hazardous Chemicals and isocyanates } \\
\text { 5. Industrial explosives - Manufacture } \\
\text { 6. Drugs and Pharmaceuticals } \\
\text { 7. Power including generation (except Atomic energy); } \\
\text { transmission, power trading, and distribution } \\
\text { (FDI is not permitted for generation, distribution \& } \\
\text { transmission of electricity produced in atomic power } \\
\text { plant/atomic energy since private investment in this activity is } \\
\text { prevented and reserved for the public sector.) }\end{array}$ & $\begin{array}{c}100 \% \\
100 \% \\
100 \% \\
49 \% \\
\text { Beyond } 49 \% \\
100 \% \\
100 \% \\
100 \% \\
100 \%\end{array}$ & $\begin{array}{c}\text { Automatic } \\
\text { Automatic } \\
\text { Automatic } \\
\text { FIPB } \\
\text { Automatic } \\
\text { Automatic } \\
\text { Automatic } \\
\text { Automatic }\end{array}$ \\
\hline
\end{tabular}

\section{FDI PROHIBITED SECTORS}

The following are the sectors/activities where FDI is strictly prohibited under any route.

1. Atomic Energy Generation

2. Any Gambling or Betting businesses

3. Lotteries (online, private, government, etc.)

4. Investment in Chit Funds

5. Nidhi Company

6. Agricultural or Plantation Activities (although there are many exceptions like horticulture, fisheries, tea plantations, Pisciculture, animal husbandry, etc.)

7. Housing and Real Estate (except townships, commercial projects, etc.)

8. Trading in TDR's

9. Cigars, Cigarettes, or any related tobacco industry

\section{FDI TRENDS IN INDIA}

The Department for Promotion of Industry and Internal Trade (DPIIT) in its annual report 2018-19 has stated that "The country registered the highest FDI inflow of $\$ 64.37$ billion during 2018-19. Foreign Direct Investment (FDI) worth $\$ 286$ billion has been received in the last five years". Highlighting the importance of FDI, it also said that the foreign inflows bring in resources, the latest technology, and best practices to push economic increase on to a higher trajectory. India has become the most attractive emerging market for global partners (GP) investment for the coming 12 months, as per a recent market attractiveness survey conducted by Emerging Market Private Equity Association (EMPEA).

India continues to rank in the top 10 countries with the highest FDI inflows as per United Nations Conference on Trade and Development (UNCTAD)'s World Investment Report (WIR). The following chart depicts the amount of FDI inflows into India from the year 2010 to 2019. 


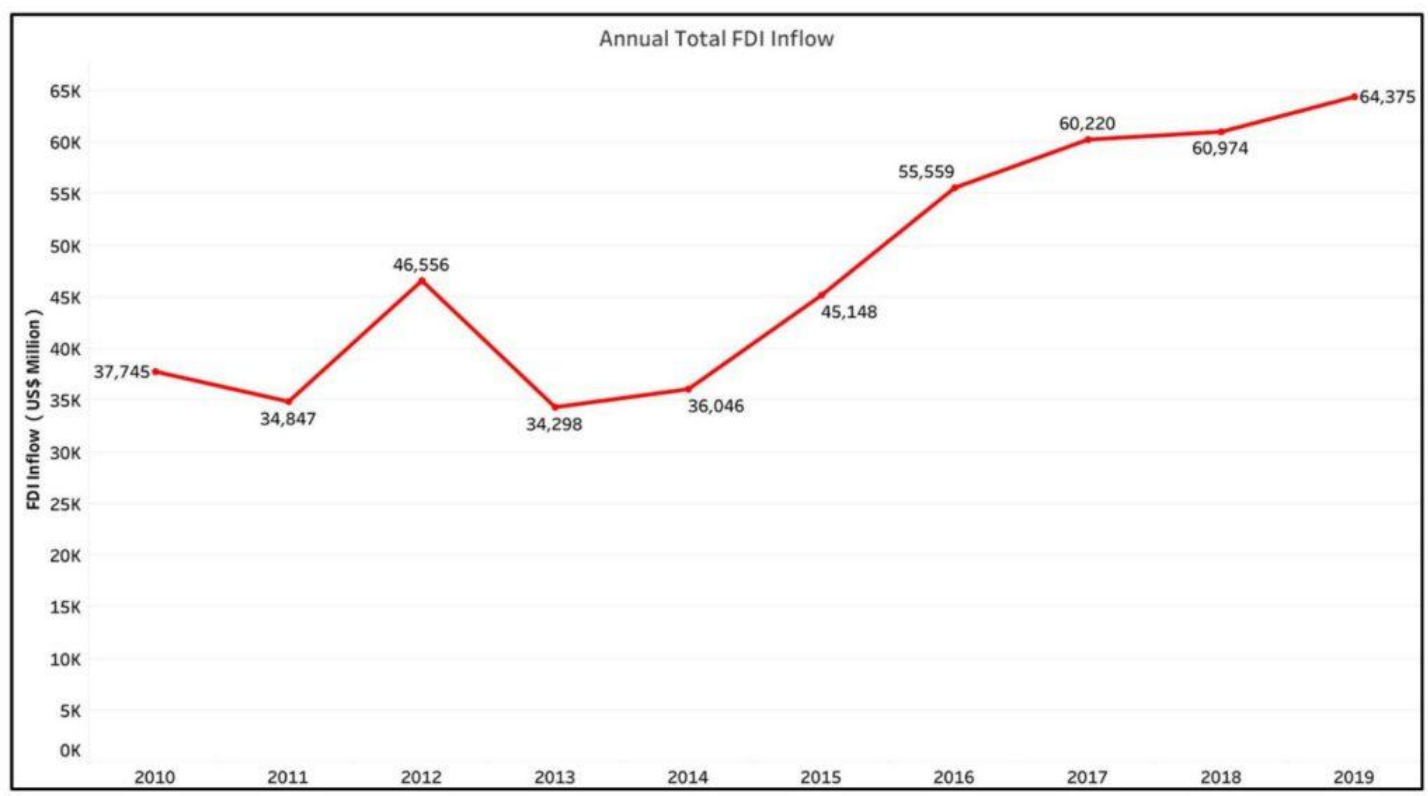

\section{SOURCES OF FDI IN INDIA}

The amount of FDI from various countries into India is dependent on multiple reasons. A considerable share of FDI comes from those countries which are allowed as tax havens. It also depends on the tax avoidance treaties signed with various countries. Double Tax Avoidance Agreement (DTAA) aims to promote investment by eliminating double taxation. India currently has signed DTAA with more than 90 countries. While the Double Tax Avoidance Agreement (DTAA) is seen as an encouragement, concerns are requested about the misuse of them for round-tripping, tax avoidance, money laundering, etc. This is especially the case with countries like Singapore, Mauritius, and Cyprus, etc. which are known to be tax havens. In the year 2016, The Government of India has amended the treaties with Singapore, Mauritius, and Cyprus. Singapore, Mauritius, and Japan are the leading sources of FDI for India. In India, Mauritius is the leading source of FDI. In 2018-19, Singapore overtook Mauritius as the top investing country with highest FDI.

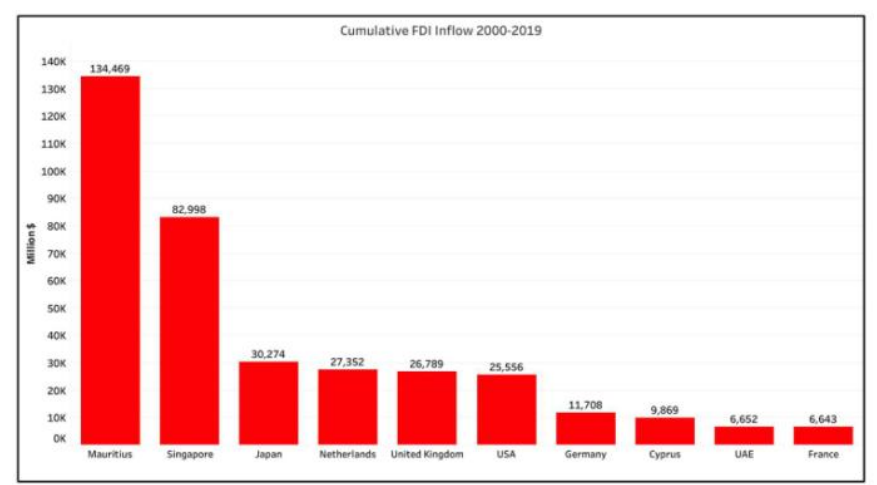

Source:

https://factly.in/in-the-last-19-years-more-than-50-of-the-fd i-was-routed-through-mauritius-singapore/

\section{FDI AND MAKE IN INDIA}

The Make in India initiative of the Government of India aims at utilizing the existing Indian talent base, creating additional employment opportunities and empowering secondary and tertiary sector. It also intends to improve India's rank on the Ease of Doing Business index by eliminating the unnecessary laws and regulations, making bureaucratic processes easier, making the government more transparent, responsive, and accountable. India has become one of the most favorable investment destinations in the world with the help of these campaigns.

25 sectors have been identified under 'Make in India' initiative, viz., (i) Auto Components, (ii) Automobiles, (iii) Aviation, (iv) Biotechnology, (v) Chemicals, (vi) Construction, (vii) Defence Manufacturing, (viii) Electrical Machinery, (ix) Electronic System Design and Manufacturing, (x) Food Processing, (xi) IT and BPM, (xii) Leather, (xiii) Media and Entertainment, (xiv) Mining, (xv) Oil and Gas, (xvi) Pharmaceuticals, (xvii) Ports, (xviii) Railways, (xix) Roads and Highways, (xx) Renewable Energy, (xxi) Space, (xxii) Textiles, (xxiii) Thermal Power, (xxiv) Tourism and Hospitality and (xxv) Wellness.

Since the launch of the Make in India campaign in September 2014, gross FDI inflows have increased substantially by $32 \%$ to US\$64.8bn, compared with a $16 \%$ increase in the 15 months before the campaign. The main sectors attracting Foreign Direct Investment include Services, Telecommunication, Computer Hardware, and Software development, Construction, and automotive. Make in India enterprise has been responsible for garnering increased flow of FDI within the nation, 


\section{FDI and Make in India}

resulting in increased Ease of Doing Business (EODB) ranking for India from 142nd rank in 2014 to 77 th place in 2018.

Government has recently launched Make in India 2.0 with a renewed focus on ten sectors including capital goods, auto, defense, pharma and renewable energy to push growth in manufacturing and generate job opportunities. The Government of India is trying hard to make India one among the top 50 nations in the World Bank's ease of doing the business report. India has access to a reserve of skilled and highly educated talents. This untapped resource, combined with the manufacturing sector, can act as a key in increasing production capacity and thereby propel India towards becoming an economic Super Power.

\section{CONCLUSION}

According to the World Investment Report 2019 released by the UN Conference on Trade and Development (UNCTAD), global FDI flows slid by 13 percent in 2018, the third consecutive annual decline. However, FDI in India, the sub region's largest recipient rose by 6 percent with strong inflows in manufacturing, communication, financial services, and cross-border merger and acquisition (M\&A) activities. The report also added that India has historically accounted for 70 to 80 percent of inflows to the sub-region and also would be among the top 10 most important sources of FDI for the period 2019 to 2021. The government in July 2019 proposed relaxation in the FDI norms for sectors such as media, aviation, insurance, and single-brand retail to attract more overseas investment. All these structural reforms undertaken will take India to its potential GDP growth of $8 \%$ to $10 \%$ in the future, and thereby India would remain one of the fastest-growing economies of the world.

\section{REFERENCES}

1. https://www.ibef.org/economy/foreign-direct-investment.aspx

2. https://www.ibef.org/pages/37752

3. http://www.makeinindia.com/documents/10281/0/Consolidated+FDI+Pol icy+2017.pdf

4. https://www.toppr.com/guides/commercial-knowledge/government-polici es-for-business-growth/fdi-in-india/

5. https://dipp.gov.in/sites/default/files/ru497 0.pdf

6. https://www.rbi.org.in/scripts/bs_viewcontent.aspx? Id=2513

7. https://factly.in/in-the-last-19-years-more-than-50-of-the-fdi-was-routed-th rough-mauritius-singapore/

8. https://nexia.com/insights/global-insight/make-in-india-campaign-boosts-f di-inflows/

9. http://pib.nic.in/newsite/PrintRelease.aspx?relid=138079

10. https://www.opindia.com/2019/04/how-make-in-india-initiative-is-acceler ating-fdi-investment-in-india-and-helping-india-emerge-as-the-fastest-gr owing-economy/

11. https://www.businesstoday.in/current/corporate/fdi-flows-to-india-grew-6in-2018-to-42-billion-world-investment-report-2019/story/355635.html

12. https://www.moneycontrol.com/news/business/economy/budget-2019-gov t-proposes-fdi-norm-relaxation-in-media-aviation-insurance-single-brand -retail-4173261.html

13. https://www.investindia.gov.in/why-india
14. https://www.investindia.gov.in/foreign-direct-investment

15. http://madaan.com/fdiapprovals.html

16. https://economictimes.indiatimes.com/news/economy/finance/india-receiv ed-highest-ever-fdi-worth-usd-64-37-billion-in-fy19/articleshow/704543 27.cms

17. https://www.ijsr.net/archive/v6i3/ART20171742.pdf

18. http://www.indianjournals.com/ijor.aspx?target=ijor:zijmr\&volume=8\&is sue $=9 \&$ article $=039$ 